\title{
From Pacifists to Cowboys to Torturers: The Different Representations of the US Military and Intelligence Agencies in Post-9/11 American War Films
}

Keywords: 9/11, military, terrorism, war-on-terror, political change

Abstract: The horrifying images of the terrorist attacks on New York's World Trade Center on 11 September 2001, in which three thousand civilians were killed, have become some of the most famous images ever committed to film or television. In the decade following the attacks, a wealth of war films were released, including Redacted (Brian De Palma, 2007), The Hurt Locker (Kathryn Bigelow, 2009) and Zero Dark Thirty (Kathryn Bigelow, 2012) amongst many others. Many films from this period of US cinema addressed both the 9/11 attacks as well as the US military's conflicts in various countries suspected of harboring terrorist groups. When analyzing the ways the military and intelligence agencies (such as the CIA) are represented in some US films from this period, it becomes clear that such representations changed over just a few years: Redacted showed the military to be polarized-a place for pacifists, rapists and murderers. The Hurt Locker later depicted successful soldiers as having a "gung ho" attitude, and the military as a permanent fixture in Iraq. Finally, Zero Dark Thirty included scenes of CIA torture, which is suggested as being necessary and justified. Surprisingly, however, the ways the military and intelligence agencies are represented in these films did not necessarily mirror the political change that was occurring.

The period between 2005 and 2008 saw the release of a high number of 9/11-related films.

Also, during this time America saw a change in government administration-from Republican to Democrat, from Bush to Obama — with the latter becoming the first black president of the United States, which suggested a change in the American mind-set which had been established in the early years of the twenty first century. This article analyzes the ways the US military and intelligence agencies (such as the CIA) are depicted in three war films released in the years immediately following the terrorist attacks of 9/11. The texts focused on here were released in 2007, 2009 and

\footnotetext{
* Phil Hobbins-White is a Film and Media teacher in the UK, and has written for various film journals, magazines and websites. He has a Masters in Film (Birkbeck, 2016), and a Masters in Media (University College London, 2011).
} 
2012 - a period which saw not only a change of President, but also significant changes in the public's opinions of the war in Iraq. A vast number of "war on terror" films were released during this decade, and due to the war dominating the news being consumed through other media platforms, there was eventually a risk of over saturation. This, in addition to the ways the war was portrayed on film, resulted in some of these films being to be more popular than others at the box office.

The first text discussed in this article, Redacted, is set in and around Camp Carolina in Iraq in 2006, focuses on the activities of a number of the serving soldiers there. The film primarily depicts the soldiers' movements during daytime patrols along with evenings at the barracks. One evening, two of the more aggressive members of the group (Rush and Flake) decide to visit the home of a local Iraqi family, during which they rape a fourteen-year-old girl and murder her family. The next film, The Hurt Locker, is based on the first-hand experiences of scriptwriter Mark Boal, who was embedded as a journalist with an Explosive Ordnance Disposal unit in Iraq. Similarly to Redacted, The Hurt Locker also explores the dangers facing the US military in Iraq, as well as the relationships of the members of the regiment, including that of Sgt. William James and a local Iraqi boy. Finally, the narrative of Zero Dark Thirty follows the US military and CIA's pursuit of Osama bin Laden, the tactics used in order to obtain information (including torturing terrorist suspects), and the eventual killing of bin Laden.

In the months immediately following the $9 / 11$ attacks, a surge in patriotism was most commonly symbolized by the American flag, appearing on porches, billboards and cinema screens across the nation. Many Americans were unified in their desire for both vengeance and answers following the attacks, emotionally investing in the idea of the American identity and way of life. Media platforms - and especially cinema - have always been important to the shaping of US 
national feeling and identity from the twentieth century onwards. Just as the propaganda films of Frank Capra had done during World War Two, a similar model which reinforced "the kind of patriotic, pro-America" sentiment was "desired by the White House" (Prince 80). In terms of the shaping and construction of an American national identity, Guy Westwell, a prominent scholar in the field of post-9/11 war cinema, argues that "the strong investment in the idea of the nation can be related to the events of $9 / 11$ " and that particular films suggest "a making, unmaking and remaking of US national identity in the decade following the terrorist attacks" (3). It is this notion - the regular revision of US military identity through cinema-which this article is concerned with.

Following the terrorist attacks of 9/11, changes occurred in American cinema almost immediately, happening in various ways. One of the immediate reactions within the American film industry (primarily Hollywood) was to remove any reference to "the twin towers" of the World Trade Center, which were destroyed in the attacks. This included removing images of the towers from a number of films, including seemingly non-9/11 related films such as Men in Black II (Barry Sonnenfeld, 2002) and from the promotional material of Spider-Man (Sam Raimi, 2002). In addition to this, other films' release schedules were pushed back—such as Collateral Damage (Andrew Davis, 2002) — as it was feared the previously planned release date was too soon for the film's terrorist/action narrative.

Hollywood did not want to generate negative publicity by appearing to 'cash in' on the tragedy, however war films with particularly patriotic tones—including Black Hawk Down (Ridley Scott, 2001) and Behind Enemy Lines (John Moore, 2001) - were amongst those films to be released earlier than previously scheduled. Westwell argues that films such as these "depicted the US as victim and showed the moral imperative of military intervention, thereby corroborating the 
wider call to war" (9). The portrayal of characters as victims gains further significance when violence is portrayed in films. When considering the ways that Hollywood films had justified the use of violence in the past, Alison Young states that "the violence of wrongdoing is wrong, whereas the violence which responds to wrongdoing is righteous" (24). Furthermore, Mark Lacy comments on the nature of cinema legitimizing one particular side's position and righteous actions, by saying: "The cinema becomes a space where 'common sense' ideas about global politics and history and reproduced and where stories about what is acceptable behavior from states and individuals are naturalized and legitimated" (614).

The manipulation of the theatrical release schedule demonstrates the first examples of the role American cinema might play in the 9/11 war effort. According to Westwell, Karl Rove, special advisor to the Bush administration, met with representatives from the entertainment industries to discuss how they might be able to contribute to the war on terror (Westwell 15). Whether as a result of such a meeting or not, a wealth of 9/11-related films were produced in the years immediately following including documentaries such as Fahrenheit 9/11 (Michael Moore, 2004), thrillers including Rendition (Gavin Hood, 2007), action films such as The Kingdom, (Peter Berg, 2007), and allegorical films including Cloverfield (Matt Reeves, 2008). The importance of the "9/11 image" in media has been highlighted by Klaus Dodds, who proclaims that "image making has been central to the war on terror-from the burning towers of the World Trade Center to the 'mission accomplished' moment of May 2003 and, more recently, the exposure of prisoner abuse, and rendition in a variety of locations around the world" (1621).

Brian De Palma's Redacted (2007), an overtly political but commercially unsuccessful war film, was released during a period which saw a particularly high number of 9/11-related American films produced. The film is loosely based on the 2006 "Mahmudiyah killings"-namely the gang- 
rape and murder of fourteen-year-old Aber Qassim Hamza, and the murder of her family by five US soldiers. The ways the military are presented through Redacted's main characters varies greatly, with the squadron containing a combination of racist murderers (Rush and Flake), juxtaposed with the honorable McCoy, who is forced at gun-point to witness the murders of the Iraqi family, but later bravely informs his superiors of the incident. The military is also shown to be a shelter and sanctuary for people who do not fit the typical idea of honor and upstanding citizenship which is historically associated with soldiers. For example, the main protagonist, Private Salazar, openly admits on numerous occasions that he only signed up for the military in order to fund his application to the USC Film School. His camcorder is regularly used as a storytelling-device (through the guise of a documentary he is making to aid his Film School application); this is shown by Salazar spending more screen time documenting life at the barracks than out on patrol. The sense that the military attracts misfits or people with ulterior motives is extended further when Flake is caught by Salazar's camera discussing his life prior to joining the military: "I just hung out, ya know, fucking around. Getting drunk trying to stay out of jail." In fact, as the film's plot develops, that is exactly what Flake continues to do, which in turn suggests that the military has given him none of the discipline that he possibly joined to gain. The lack of discipline possessed by military personnel is confirmed further by the scene which gives the film its narrative drive, in which Flake (and his equally deplorable partner, Rush) are shown playing poker, getting drunk, then going to kill an innocent Iraqi family and rape their 14-year-old daughter.

In addition to the negative depiction of soldiers such as Flake and Rush as highlighted in the examples above, Flake is also at fault in an incident which leads to the death of a pregnant Iraqi civilian earlier in the film. Supposedly on watch at a security checkpoint, whilst having the responsibility for a machine gun positioned on top of the troop's tank, Flake falls asleep in charge 
of the weapon, only to be woken suddenly by the sound of the civilian's car, leading to him impulsively firing bullets, killing the Iraqi. This murder of the innocent civilian, coupled with the later rape of the Iraqi girl and murder of her family, understandably causes conflict between the assailants and the film's comparative "positive" characters, McCoy and Blix. McCoy, who is psychologically threatened by Flake and Rush and physically harmed by the pair both prior to and after the murder/rape due to his unwillingness to take part in the crime, demonstrates his bravery by informing his commanding officers of the incident. Whilst it could be assumed that McCoy's disclosure of the events surrounding the rape of the young Iraqi teenager and murder of her family would act as catharsis for him, the film's final scene (excluding the real-life still-images of war victims), confirms the contrary. In this scene, McCoy starts by thoroughly enjoying a social evening with his wife and friends back in the US However, when his friends ask for a 'war story' the only one which McCoy feels able to relay is the story of the rape and murder, the memories of which cause McCoy to break down in distress. The permanence of these harrowing memories is finally captured in a still-photo image of McCoy and his wife, their tears and soulless expressions suggesting irreparable psychological scarring.

In addition to the 'positive' character of McCoy, who is positioned as a polar opposite to the deplorable pair of Flake and Rush, we can compare another of the main protagonists, Blix. He is often shown seemingly deep in thought, reading John O'Hara's Appointment in Samarra (a relatively high brow book compared to Flake's reading material, Hustler magazine). In one scene where the audience is introduced to Blix through the gaze of Salazar's documenting camcorder, a whip-pan allows for an immediate juxtaposition between Blix's novel and Flake's trash magazine. Here, De Palma is simultaneously challenging and confirming stereotypes of male military personnel: Blix's reading of Appointment in Samarra and Flake's reading of Hustler. Further to his 
suggested (relative) intellectualism, Blix is also portrayed as a pacifist. Several examples point towards this: firstly, Blix's job-K-9 handler-involves the use of a dog to detect bombs, as opposed to a role which directly requires the use of weaponry and aggression. Additionally, Blix enquires to his superior officer about whether the platoon have completed their final deployment, suggesting he would like to be relieved of his duties and return home. Finally, Blix is positioned as being the opposite of Flake and Rush by doing everything in his power to prevent their sexually aggressive plan, however his physical inferiority renders him useless. Through the depiction of Blix as an intellectual and pacifist, aligned with the honorable McCoy, De Palma has created characters who are the polar opposites of Flake and Rush, which mirrored the divided nature of opinion of the war on terror felt by the American public around the time of Redacted's release.

Through Redacted, director Brian De Palma created a critique of US foreign policy and its involvement in the war in Iraq. By drawing inspiration from controversial actual events (such as the Mahmudiyah killings), as well as the inclusion of despicable characters such as Flake and Rush, who are members of the military but also rapists and murderers, De Palma's intention was to allow Redacted to convey the messages and images which he feels often get redacted in the war narratives told by television news. De Palma himself commented on the (un)availability of such controversial war images - the types of images which do not comply with some mainstream media's agendas — by saying: “The war has been redacted from the major media. We don't see the carnage, we don't see the innocent civilians killed. That's what the architects of this war learned from Vietnam: get it off the mainstream media" (qtd. in Prince 302).

The year of Redacted's release, 2007, was an interesting time as far as this study is concerned, with many changes occurring in the political zeitgeist. Change had been signaled by the emergence of Barack Obama, who had announced himself as a candidate for the presidency. 
Furthermore, there was a change in the public opinion surrounding the legitimacy of the war on terror, and quite crucially, there was also changing audience appetite for war on terror films. Whilst Gallup polls in 2007 suggested that $60 \%$ of Americans believed waging war in Iraq was a mistake (Jones), there appeared to be a decreasing appetite for 'serious' war on terror related films at the US box office. For example, the second half of 2007 alone saw the release of In the Valley of Elah (Paul Haggis, 2007), The Kingdom (Peter Berg, 2007), Lions for Lambs (Robert Redford, 2007), A Mighty Heart (Michael Winterbottom, 2007) and Rendition, all of which only broke even at the box office. An exception to this was Lions from Lambs, which performed comparatively better commercially worldwide, but recouped relatively low domestically (\$15 million) compared to its budget of \$35 million (Box Office Mojo).

Redacted was a major flop at the box office, struggling to recoup even half a million dollars. Similar commercial disappointment was suffered by Stop-Loss (Kimberly Pearce, 2008), another film which criticized the war on terror. The lack of box office success experienced by these films was possibly suggesting that audiences had become saturated by media coverage of the war on terror, and they no longer wanted to be reminded of it when they visited the cinema. In addition to the subject matter of the war on terror, other factors might have also contributed to why these films lacked appeal. Paul Farhi, writing in The Washington Post in early 2008, commented on such films' lack of popularity with audiences, by stating: "The only things less popular than the war itself are dramatic films and television shows about the conflict... Are audiences turned off by the war, or are they simply voting against the way filmmakers have depicted it?" ("The Iraq War"). This query highlights a possible disparity between the ways audiences would like such serious subject matter handled, and the decisions of filmmakers to portray the war on terror in a certain way. 
The Hurt Locker (2009), released during Barack Obama's first months of presidency, was a war on terror film which enjoyed commercial and critical success. Although the film was ready for distribution in 2008, it was not officially released until June 2009 after a long and successful tour of multiple festivals. Whether it was the delayed release which benefited The Hurt Locker, or possibly, as Farhi suggests, box office popularity was gained in the ways war was depicted, the film was a success, both financially and critically. Following on from winning in six categories at the Academy Awards - most notably Kathryn Bigelow becoming the first female to win the Award for Best Director — the film bucked the trend of poor box office returns for war films.

One of the reasons for the film's success could relate to the varied and complex mixture of characterizations and military representations. Furthermore, the film's characters offer many examples where multiple, conflicting readings are also possible. However, unlike Redacted, the representations of the military given here are not completely polarized, and offer somewhat more complex and ambiguous readings. The Hurt Locker's narrative opens with the closely-knit group of EOD experts, with the dialogue making it clear that they have close relationships-both personal and professional — with each other. The characters' diligence to their tasks further demonstrates their professionalism, and each of the group are fully prepared with equipment, strategy and knowledge. Whilst this is true, the popular and respected Sgt. Thompson is killed and is soon replaced by Sgt. James, who offers the audience a completely different depiction of the military. It is made clear that James favors a solo approach to his work; he immediately places barriers between himself and the team-oriented Sgt. Sanborn, such as playing loud, heavy rock music, changing the layout of the shared-living quarters, and choosing to remain in his own company. James can be considered to represent the future-perhaps best-evidenced by his youth 
and his ability to survive multiple life-threatening situations - and as such suggests that the military is a place of individuals, of "dog-eat-dog," and not "united we stand."

Stereotypically the military is a place of rules, hierarchy and respect for superiority. However these conventions are completely dispelled during James' first mission with the unit, during which he does not follow protocol or the advice from the experienced members of the unit. It is clear from Sanborn's shouted reactions and constant asking for clarification that he is neither used to working in this manner, nor willing to. An immediate distinction is drawn between him and James, who, after casually tossing a gas canister behind him and blindly walking into the unknown through the smoke, creates yet another barrier. James then replies to Sanborn's request of his proximity to the IED with "Hell, I don't know, but I'll tell you when I'm standing over it, cowboy.” Again, this shows James' willingness to operate as an individual, breaking traditional depictions of the military as a team-oriented environment.

When James is with local Iraqi people he is less anti-social and individual-minded however. He strikes up a friendship with "Beckham," a young Iraqi boy who sells counterfeit DVDs, and it is here that James is represented for the first time as his natural self: someone who has completely lost his connection with America, and instead only knows Iraq and war. James' relationship with Beckham can be considered as that of a combination of father figure and older brother; in one scene James teasingly offers Beckham a cigarette only to snatch it away, and later challenges him to a duel with a football penalty kick. The genuine fondness that James holds for Beckham is further confirmed when the Iraqi boy is believed to have been killed, as James finds the bloodied corpse of a boy resembling Beckham. Here, James' distress is visually made clear, as he sets out to find the perpetrators, demonstrating how much he cared for the young Iraqi boy. 
James' connection with Iraqis and lack of connection with Americans is reinforced in a scene when he arrives with the aim to diffuse an IED suspected in a car. Upon arrival, James teases an Iraqi police officer by suggesting it should be his job to take the first look, eventually admitting that he is joking. This can be juxtaposed with James' lack of communication with Sanborn only minutes later, when James is so frustrated with giving Sanborn updates over the radio that he completely discards his headset, potentially jeopardizing the mission and all their lives. This representation of a member of the military being selfish and unprofessional completely contradicts typical depictions and expectations, once again.

James' disconnection with his fellow soldiers, along with his sincere caring for Iraqis, is regularly juxtaposed with Sanborn, who displays more typical representations of military conduct. Sanborn and James regularly disagree with one another's approach, with James' laid-back individualism the polar-opposite to Sanborn's professionalism and keenness to follow protocol. Indeed, in one scene following a particularly fractious encounter, Sanborn even hints at being tempted to murder James by staging an accidental explosion. Here, Sanborn is portrayed as being too used to the norm of killing in Iraq, and again shows US military personnel as individuals seeking personal gain, rather than as a united group.

The Hurt Locker's plot and narrative structure also provide the audience with representations of the US military. The film's plot essentially follows an episodic format of one bomb-disposal tableau after another, with each episode proving more difficult. This seemingly repetitive, never ending mission is reinforced further by James returning to Iraq at the film's close, to start another dangerous mission, creating a circular narrative, rather than a linear one. Furthermore, the metaphors created by the film's circular nature, and the suggestion of there being no end to the conflict, was commented upon by Joshua Clover, who argues that the "episodic 
aimlessness" which “... summons up the unnarratability of the Iraq adventure, its unreason, and inevitably the idea that there was no reason to start with" (9). However, given that James actively chooses to start another rotation in Iraq at the film's conclusion, also represents the military-even with its obvious dangers - as an attractive alternative to family life back in America. If this reading is accepted, audiences have been offered a noticeable shift, then, from the horrors of murder and rape offered by Redacted in 2007, to something presenting the military as an attractive proposition in 2009 .

Following the critical and commercial successes of The Hurt Locker, Kathryn Bigelow and screenwriter Mark Boal's next project was to chronicle the US military's search for suspects in the 9/11 attacks, most notably Osama bin Laden. Zero Dark Thirty's narrative is told primarily through the activities of the CIA at various black sites, and includes scenes of torture by CIA agents in order to obtain intelligence information. The film opens with real audio recordings from the 9/11 attacks using radio recordings from the first responders such as the New York Police- and FireDepartments. Further authenticity is established by the use of audio of a person trapped in the wreckage of the World Trade Center, who is on the verge of being burnt alive. Following this audio, a scene shows CIA agent Dan, along with the watching presence of newly arrived CIA agent Maya, torturing a suspected terrorist.

The 'alternative interrogation methods' which occurred at CIA 'black sites' as depicted in Zero Dark Thirty's opening scenes were authorized by then-national security adviser Condoleezza Rice in 2002, as the US intensified the search for answers about the 9/11 attacks ("Senate Report"). The methods being referred to by Rice involve the process of rendition — or 'torture by proxy' in which a suspect is kidnapped and transferred from one country to another, and subject to extraordinary rendition, the process of various forms of torture in order to obtain information. 
Vice-President Dick Cheney openly discussed the strategy, referring to torture methods as "the dark side," saying that "a lot of what needs to be done here will have to be done quietly, without any discussion, using sources and methods that are available to our intelligence agencies, if we're going to be successful" (qtd. in Froomkin). Cheney's assertion that the United States should go to "the dark side" in the war on terror was a particularly relevant topic in the development of American cinema's output in the post-9/11 era. In the year prior to Cheney's statement, pictures emerged of a series of human rights violations against detainees at the Abu Ghraib prison in Iraq, including physical torture, waterboarding, sexual abuse and murder. Following on from this, The Washington Post and Human Rights Watch published further information regarding CIA black sites, which essentially operated as secret prisons where rendition took place. In the post-9/11 era, extraordinary rendition became more commonplace as the war on terror and the hunt for Osama bin Laden intensified, despite public protest around the world.

Zero Dark Thirty's scenes of torture are particularly difficult to watch, which Bigelow makes clear by her camera not shying away from the violence, often capturing the torture in closeup. However, as the audience have been provided the real audio from first responders to the $9 / 11$ devastation in the previous scene, the actions of the CIA torturers are the "violence which responds to wrongdoing [and] is [therefore] righteous," as Alison Young has stated (24). Furthermore, by directly linking the scene of the first responders' audio and the torture scenes through editing, Bigelow is making a clear connection between the 9/11 attacks and this prisoner, of which Manohla Dargis claims creates "a cause and effect relationship between the void of September 11 voices and the lone man strung up in a cell" (qtd. in Westwell 173). By presenting this connection, the audience is positioned alongside the torturing CIA agents, and by watching this act, the audience members are also implicated in the crime. These scenes could be considered as propaganda which 
justify the illegal and inhumane actions of the CIA in their pursuit of intelligence. Zero Dark Thirty's seeming-justification of torture recalls Stephen Prince's assertion that war films can offer "the kind of patriotic, pro-America" (80) propaganda. In this example, the message is one which would aid the White House in their quest to regain support for their war on terror.

Through the film's narrative structure of causal episodes in which terrorist attacks are crosscut with the American responses, the CIA (and the military by extension) are represented as being both regularly under threat, as well as constantly working to find a different solution in the hunt to find Osama bin Laden. Indeed, the cause-and-effect nature of the narrative continues beyond the film's opening scenes, as Dan explains this very premise to their prisoner that theirs is not a normal prison: "You decide how you are treated," he says. Here, the CIA are represented as being blameless in the practice of torture by suggesting that it is the prisoner's fault if he is being tortured.

The main character of Maya is regularly portrayed as being highly motivated to achieve her mission's objectives of finding Osama bin Laden, whilst operating in the typically maledominated environments of the CIA, White House politics and the military. Two crucial scenes show Maya's confidence in both her convictions and information: in one scene, senior CIA and White House delegates meet to discuss the likelihood of having tracked-down Osama bin Laden. The opinions of the experienced, (male) decision-makers are sought, all of whom concur there is a sixty to eighty percent chance that Osama bin Laden has been located. Maya on the other hand, very forcefully declares that she is one hundred percent certain the figure on the satellite image is their target, which ultimately proves to be correct. Maya's confidence is reinforced in a later scene when she states to skeptical members of the Navy SEAL team that "bin Laden is there. And you're going to kill him for me" in a very forthright manner. By demonstrating Maya's complete 
confidence that bin Laden has been found, Zero Dark Thirty makes the connection between torture and correct and useful information, and therefore suggests the justification of torture in these terms.

Upon the narrative's conclusion, with Maya's mission complete following the death of Osama bin Laden, she is shown in the vast, empty hold of a cargo plane. She is asked where her destination is, but after a long pause she does not answer. As Maya does not know her destination—-both immediately and figuratively—we can consider the physical and psychological toll the mission has had on her. The post-9/11 war waged by the CIA and the military are suggested to have initially given Maya her purpose, but then taken it away at the mission's end. Upon learning of the death of bin Laden, Maya does not experience the anticipated feelings of relief and accomplishment, but instead has been left directionless and dehumanized by the experience. The sense of dehumanization that Maya suffers can be compared to the main characters of Redacted's McCoy and The Hurt Locker's James: both can also be considered to have been dehumanized by the military and the war on terror-McCoy the subject of Redacted's final shot with psychological scarring apparent, and James returning to Iraq for another rotation in The Hurt Locker.

Torture plays a significant role in Zero Dark Thirty. The main instigator of torture is Dan, who is bearded and tired-looking, suggesting the torture has been a long-occurring event. The regular event of torture portrays the CIA as both confident and single-minded in its approach, as well as being unflinchingly committed to aggression and pain. Steve Coll comments on the significant role torture plays in the obtaining of information in Zero Dark Thirty by stating that "in virtually every instance in the film where Maya extracts important clues from prisoners, then, torture is a factor" ("Disturbing and Misleading"). The number of torture scenes in Zero Dark Thirty is telling, as is the ways these scenes are presented on-screen, and the ways the audience is impacted by these depictions. For example, many of the tortures are carried out by likeable 
characters who the audience had been drawn to; Dan is charismatic, and his role as torturer is possibly legitimized by his $\mathrm{PhD}$ — these factors potentially encourage the audience to relate to the torturers, giving full consent. In Screening Torture, Michael Flynn and Fabiola F. Salek assert that many post-9/11 Hollywood films "transmit the concept the torture can be absorbed by civil society, and the consequences for the victims, the perpetrators in the system are insignificant" (12), regularly positioning audiences to identify with torturers, rather than with the victims.

The period immediately following the 9/11 attacks-particularly between 2006 and 2008 - saw the release of a high number of American war films. The analyses of the three texts in this article have attempted to establish how representations of the US military changed during this period. Brian De Palma's Redacted provided audiences with the depiction of the military as an institution which attracts misfits and pacifists, as well as being a breeding ground for rapists and murderers. Moreover, the military is shown as being able to psychologically scar honorable soldiers who stand up for what is right. Released in 2007, Redacted was one of the many war on terror films to struggle at the box office, demonstrating audiences' lack of desire for films which approached war in such pessimistic, negative and cynical ways. The Hurt Locker, on the other hand, suffered no such problems with box office popularity two years later. Through the arguably more complex representations offered by its central protagonist, Sgt. James represents the future of the military, and possibly America too: individualistic and disconnected. The film's neverending, circular narrative also suggests the US military is a constant and necessary presence in territories such as Iraq. Furthermore, the military is depicted as an attractive lifestyle for people such as Sgt. James, which marks a noticeable shift in tone from Redacted. Finally, through Kathryn Bigelow's Zero Dark Thirty, a tonal shift is noticeable from the previous texts. Here, the audience is positioned with the CIA on their journey to "the dark side," which the film implies is necessary 
in the quest to obtain crucial information. Similarly to The Hurt Locker, the war on terror has provided Zero Dark Thirty's central protagonist with their main purpose, and also given them an identity. However, with Osama bin Laden having been killed, Maya—just like Redacted's McCoy and The Hurt Locker's Sgt. James— - has been left dehumanized by war. Throughout the decade which followed the attacks of 9/11, Guy Westwell's assertion that there was "a making, unmaking and remaking of US national identity" (3) is evident from numerous war films released during the period, especially those highlighted in this article; from Redacted to The Hurt Locker and then to Zero Dark Thirty, war and its consequences became increasingly acceptable. 


\section{Works Cited}

Clover, Joshua. “Allegory Bomb.” Film Quarterly 63.2 (2009): 8-9. Print.

Coll, Steve. "Disturbing and Misleading." New York Review of Books 7 February 2013. Web. 28 September 2020.

Dodds, Klaus. "Hollywood and the Popular Geopolitics of the War on Terror." Third World Quarterly 29.8 (2008): 1621-1637. Print.

Farhi, Paul. "The Iraq War, in Hollywood's Theater.” The Washington Post 24 March 2008. Web. 28 September 2020.

Froomkin, Dan. "Cheney's 'Dark Side' is Showing." The Washington Post 7 November 2005. Web. 28 September 2020.

Flynn, Michael and Fabiola F. Salek (eds). Screening Torture: Media Representations of State Terror and Political Domination. New York: Columbia University Press, 2012. Print.

Jones, Jeffrey M. "Latest Poll Shows High Point in Opposition to Iraq War." Gallup.com 11 July 2007. Web. 28 Sept. 2020.

Lacy, Mark. "War, Cinema and Moral Anxiety.” Alternatives 28.5 (2003): 611-636. Print.

"Lions for Lambs." Box Office Mojo. Web. 28 Sept. 2020.

Prince, Stephen. Firestorm: American Film in the Age of Terrorism. New York: Columbia University Press, 2009. Print.

Redacted. Dir. Brian De Palma. Magnolia Pictures, 2007.

"Senate Report: Rice, Cheney OK'd CIA Use of Waterboarding." CNN 23 April 2009. Web. 28 September 2020.

The Hurt Locker. Dir. Kathryn Bigelow. Summit Entertainment, 2009. 
[Inter]sections 23 (2020): 17-35

Westwell, Guy. Parallel Lines: Post-9/11 American Cinema. London: Wallflower Press, 2014. Print.

Young, Alison. The Scene of Violence: Cinema, Crime, Affect. Abingdon: Routledge, 2009. Print.

Zero Dark Thirty. Dir. Kathryn Bigelow. Sony Pictures Releasing, 2012. 